\title{
Randomised controlled trial in northern England of the effect of a person knowing their own serum cholesterol concentration
}

\author{
P J Elton, A Ryman, M Hammer, F Page
}

\begin{abstract}
Subject objective - To test the hypotheses that the knowledge that the serum cholesterol concentration is raised ( $\geqslant 6.5 \mathrm{mmol} / \mathrm{l}$ ) will lead to a reduction in the concentration after education intervention and that the knowledge that the concentration is not raised does not lead to an increase in the serum cholesterol concentration after education intervention.

Design - Prospective randomised trial, with investigators blind to the randomisation.
\end{abstract}

Setting - An industrial site in Manchester, England.

Participants - A total of 495 employees of Imperial Chemical Industries, 469 of whom completed the trial.

Main result - There was a significant reduction in the serum cholesterol concentration of those whose initial concentration was $\geqslant 6.5 \mathrm{mmol} / 1$ and who were given the result. This reduction was $0.28 \mathrm{mmol} / 1$ greater than in the control group. The reduction was similar, however, to the increase in the serum cholesterol concentration in those whose initial concentration was $<5.2 \mathrm{mmol} / 1$, regardless of whether or not they had been given the result.

Conclusion - These results support the hypotheses, although the lack of regression to the mean in the control group with high serum cholesterol suggests that this conclusion should be treated with caution.

Tameside and Glossop Health Authority, Hyde, Cheshire P J Elton

Lothian Health Board, Royal Edinburgh Hospital, Edinburgh

A Ryman

North Manchester General Hospital,

Manchester

M Hammer

Zeneca Specialties, Blackley

F Page

Correspondence to:

Dr P Elton, Tameside and Glossop Health Authority,

Greenfield Street, Hyde,

Greenfield

Accepted for publication July 1993

\section{(F Epidemiol Community Health 1994;48:22-25)}

There is a consistent association between the serum cholesterol concentration and coronary heart disease, and there is consensus that this relationship is causal. ${ }^{1-4}$ Strong evidence exists that both morbidity and mortality from coronary heart disease are reduced by lowering the serum cholesterol, although the effect on total mortality is less clear. ${ }^{3-10}$ There is also doubt about the advantages of using cholesterol reducing drugs rather than diet. ${ }^{112}$ The possibility that drugs increase mortality from noncardiac causes is particularly worrying. ${ }^{13}$ The disadvantage of diet is that it may be relatively ineffective. ${ }^{14}$

Two strategies that are not necessarily incompatible have been advocated. A reduction across the spectrum of serum cholesterol concentrations in the population has consensus support. ${ }^{15-16}$ A small shift across the entire population can have a greater effect on morbidity and mortality than a large shift in selected individuals. Not everyone, however, will respond to a population approach. It has been suggested that if people knew that their serum cholesterol concentration was high they would be more likely to change their behaviour. ${ }^{17}$ This not only remains unproved, ${ }^{1819}$ it is supported by a quasi-experimental study only, ${ }^{20}$ and may also lead those with lower cholesterol concentrations to leave their diet unchanged, thereby adversely affecting a population approach. ${ }^{21}$

This trial was designed to address these issues, to indicate whether serum cholesterol screening affected peoples' responses to education designed to encourage a change in diet. In particular, the following hypotheses were tested:

(1) The knowledge that the serum cholesterol concentration is raised $(\geqslant 6.5 \mathrm{mmol} / \mathrm{l})$ will lead to a reduction in the concentration after educational intervention.

(2) The knowledge that the serum cholesterol concentration is not raised will not lead to an increase in concentrations after educational intervention.

\section{Methods}

The trial took place between August 1991 and June 1992. Subjects were drawn from the Imperial Chemicals Industry site at Blackley, Manchester, with the following exclusions:

(1) Aged under 20 or over 65 years;

(2) Previous knowledge of their own serum cholesterol concentration.

Subjects were given sealed envelopes which randomly allocated them to an intervention group, who were told their serum cholesterol level, or a control group who were not.

Both groups were scheduled to have two serum cholesterol concentration measurements with a week's interval in between, and an average was taken as it is recognised that there can be substantial fluctuations in intrasubject serum cholesterol measurements. ${ }^{22}$ Total cholesterol was measured on a Monarch 2000 centrifugal analyser using Biostat CHOD/PAP cholesterol reagent, catalogue no 510019 (as used on the routine departmental Technicon SMAC multichannel analyser), and calibrated using the same SMAC Set Point 2 calibrator for consistent results. Normal quality control procedures were followed and full participation in external quality assur- 
ance schemes was maintained throughout the study. All subjects were asked questions about their social demographic characteristics and their perception of other risk factors.

All subjects were invited to a health education session, introduced by a doctor (AR) and then run by a dietitian, within two weeks of the second serum measurement. The session, which lasted about an hour, advocated a diet equivalent to the step 1 diet. ${ }^{14}$ All subjects were handed the sealed envelope a quarter of an hour before the start of the formal session. Subjects were asked not to discuss the contents of the letter. In the intervention group, the envelope contained one of three different letters according to whether their cholesterol concentration was $\geqslant 6.5 \mathrm{mmol} / 1,5.2-6.45 \mathrm{mmol} / 1$, or $<5.2 \mathrm{mmol} / \mathrm{l}$. While the three letters stated whether the result was "high", "not particularly high", or "below average", all three indicated that the advice in the health education session should be followed either to reduce or maintain the serum cholesterol concentration. The description of the result meant that motivation was most clearly intended for those with a cholesterol concentration $\geqslant 6.5 \mathrm{mmol} / 1$ in line with the hypotheses. For the control group there was only one letter informing the subject that they were in the control group but, that as it is worthwhile for everybody to reduce their blood cholesterol concentration, the health education would be relevant to them too. The doctor (AR) and the dietitian remained blind to the allocation.

Thirteen weeks after the initial serum measurements, two further serum cholesterol concentration determinations with a week's interval were scheduled. Analysis of serum cholesterol concentrations was based on the two means before and after the intervention. If the difference between the two measurements at either stage was more than $1.0 \mathrm{mmol} / \mathrm{l}$, a third sample was taken and the two measurements closest to each other were used to calculate an average.

The calculation of sample size required ${ }^{23}$ depends on using values from studies with a different design. In these studies, serum cholesterol was reduced as a result of dietary intervention in which all subjects with a high serum cholesterol knew this to be the case. These indicated a reduction in serum cholesterol of about $10 \% .{ }^{24}$ This would produce a reduction in the serum cholesterol concentration of about $0.7 \mathrm{mmol} / \mathrm{l}$. For an $\mathrm{SD}$ of this reduction of $0.9 \mathrm{mmol} / 1^{25}$ to achieve a power of $90 \%$ at a significance level (one tailed) of $5 \%$, 26 subjects with an initial serum cholesterol $\geqslant 6.5 \mathrm{mmol} / 1$ would be required in each group. The proportion of people in this country with a serum cholesterol $\geqslant 6.5 \mathrm{mmol} / 1$ has been reported to be $26 \%{ }^{26}$ Since this was based on one measurement, however, it is likely to be a higher proportion than results based on two measurements. If $20 \%$ of subjects were to have a serum cholesterol of $\geqslant 6.5 \mathrm{mmol} / \mathrm{l}$, then a total of 260 subjects would be required to complete the trial.

The absolute values of the serum cholesterol concentration within each result band would not be expected to follow a normal distribution, whereas the differences in the measurements between the two stages would be expected to approximate more closely to such a distribution. Because of this, the Student's $t$ test was performed on the differences between the serum cholesterol concentrations at the two stages rather than on the absolute values.

\section{Results}

A total of 239 people in the intervention group had their initial serum cholesterol concentration measured but $10(4 \%)$ failed to complete the trial, including one with an initial serum cholesterol concentration $>6.5 \mathrm{mmol} / \mathrm{l}$. The control group comprised 256 subjects who had their initial serum cholesterol measured, but $16(6 \%)$ failed to complete the trial, including three with an initial serum cholesterol concentration $>6.5 \mathrm{mmol} / 1$.

Except for gender, the social and other characteristics of the two groups at entry were similar (table 1). The higher proportion of men with low serum cholesterol concentrations in the intervention group compared with the control group does just reach the conventional level of significance $(p<0.05)$, but this is one of 18 comparisons of characteristics that were made. The lower proportion of subjects with a cholesterol concentration of 5.2$6.45 \mathrm{mmol} / 1$ in the intervention group was not statistically significant.

The mean initial and final concentrations and the change in cholesterol values in the two groups are shown in table 2 .

\section{Discussion}

The a priori hypotheses that knowledge that the serum cholesterol concentration is raised will lead to a reduction after educational intervention and that knowledge that the concentration is not raised will not lead to an increase after educational intervention seem to be

\begin{tabular}{|c|c|c|c|c|c|c|c|c|}
\hline & \multicolumn{8}{|c|}{ Serum cholesterol $(\mathrm{mmol} / \mathrm{l})$} \\
\hline & \multicolumn{4}{|c|}{ Intervention } & \multicolumn{4}{|c|}{ Control } \\
\hline & $<5 \cdot 2$ & $5 \cdot 2-6 \cdot 45$ & $\geqslant 6.5$ & Total & $<5 \cdot 2$ & $5 \cdot 2-6 \cdot 45$ & $\geqslant 6.5$ & Total \\
\hline $\begin{array}{l}\text { No } \\
\text { Mean age }(y) \\
\text { Male }(\%) \\
\text { Social class I or II }(\%) \\
\text { Present smokers }(\%) \\
\text { Subjects classifying themselves as overweight }(\%) \\
\text { 1st degree relative died of heart attack before age of } 60 \mathrm{y}(\%)\end{array}$ & $\begin{array}{l}77 \\
34 \cdot 4 \\
52 \\
77 \\
8 \\
32 \\
5\end{array}$ & $\begin{array}{l}94 \\
38 \cdot 0 \\
63 \\
80 \\
16 \\
27 \\
4\end{array}$ & $\begin{array}{l}58 \\
43 \cdot 6 \\
66 \\
84 \\
35 \\
45 \\
5\end{array}$ & $\begin{array}{l}229 \\
38 \cdot 2 \\
60 \\
80 \\
18 \\
33 \\
5\end{array}$ & $\begin{array}{l}75 \\
31 \cdot 6 \\
36 \\
85 \\
12 \\
25 \\
3\end{array}$ & $\begin{array}{l}112 \\
39 \cdot 3 \\
60 \\
76 \\
14 \\
34 \\
6\end{array}$ & $\begin{array}{l}53 \\
44 \cdot 0 \\
75 \\
72 \\
34 \\
49 \\
8\end{array}$ & $\begin{array}{c}240 \\
37 \cdot 9 \\
56 \\
78 \\
18 \\
35 \\
5\end{array}$ \\
\hline
\end{tabular}


Table 2 Serum cholesterol measurements ( $\mathrm{mmol} / \mathrm{l}$ )

\begin{tabular}{llll}
\hline & $<5.2 \mathrm{mmol} / \mathrm{l}$ & $5.2-6.45 \mathrm{mmol} / \mathrm{l}$ & $\geqslant 6.5 \mathrm{mmol} / \mathrm{l}$ \\
\hline Intervention initial serum cholesterol & 4.62 & 5.74 & 7.13 \\
Control initial serum cholesterol & 4.59 & 5.83 & $7 \cdot 12$ \\
Intervention final serum cholesterol & 4.84 & 5.81 & 6.84 \\
Control final serum cholesterol & 4.85 & 5.81 & $7 \cdot 12$ \\
Intervention mean change & +0.22 & +0.07 & $-0.29^{*}$ \\
$(95 \% \mathrm{CI})$ & $(0.13,+0.31)$ & $(-0.02,+0 \cdot 17)$ & $(-0.48,-0 \cdot 11)$ \\
Control mean change & +0.26 & -0.02 & $-0.01^{*}$ \\
$(95 \% \mathrm{CI})$ & $(0.13,+0.38)$ & $(-0.15,+0 \cdot 11)$ & $(-0.16,+0.15)$ \\
p (for mean change) & 0.67 & 0.26 & 0.024 \\
\hline
\end{tabular}

* The difference between these two values reaches the conventional level of significance given in the last line of the table. power calculation. This was in line with the changes in serum cholesterol values in controlled trials of step 1 or an equivalent diet that were summarised after this study had begun. ${ }^{14}$ The power of the trial was increased by the use of two measurements of serum cholesterol to give the initial and final values. This would be expected to increase the reliability of the results and thereby reduce the SDs. The SDs for the mean changes in the intervention and control groups in this study were 0.58 and $0.72 \mathrm{mmol} / \mathrm{l}$ respectively. It may be that the power of any future trial with the same number of subjects could be increased by using measurements excluding high density lipoprotein cholesterol, which have an inverse relationship with coronary heart disease ${ }^{2728}$ and do not decline with a conventional lipidlowering diet. ${ }^{29}$ The measurement of low density lipoprotein cholesterol does change the identification of some individuals as having a raised value. ${ }^{25}$

An issue that needs to be considered is whether three months is too short a period to consider. It was not thought practical or ethical to use a longer period, even though it might have been desirable. There is evidence that changes found at five months are similar to those found at one year, ${ }^{31}$ indicating that it is worthwhile looking at a short period to ascertain change.

These results do indicate that there might be benefit in a further trial on this matter, despite the previous negative result from the Aylesbury study. ${ }^{19}$ Any further trial should consider the nature of the educational content, as effectiveness may depend upon whether this concentrates on dietary advice, as in this study, or is part of a package of health education advice, as in the Aylesbury study. It may be that a much larger trial, based on a factorial design, could elucidate any contribution of either, or both, health education and risk labelling.

The dietitian who ran the educational sessions was E Trier and the administrative work for the study was undertaken by $\mathrm{E}$ Lloyd. This study was facilitated by staff at ICI, in particular $G$ Lloyd. This study was facilitated by staff at ICI, in particular $G$
Turner, $M$ Davis, $S$ Healey, A Holmes, and S Hadfield. The statistical analysis was undertaken by B Harbin.

1 Kannel WB, Castelli WP, Gordon T, McNamara PM. Serum cholesterol, lipoproteins and risk of coronary heart disease, the Framingham study. Ann Intern Med 1971;74:1-12.

2 Lipid Research Clinics Program. The Lipid Research Clinics Program coronary primary prevention trial results. I - Reduction in incidence of coronary heart disease. fAMA 1984;251:351-64.

3 Multiple Risk Factor Intervention Trial Research Group. Multiple Risk Factor Intervention Trial: risk factor changes and mortality results. $\mathcal{F} A M A$ 1982;248:1465-77.

4 Martin MJ, Hulley SB, Browner WS, Kuller LH, Wentworth D. Serum cholesterol, blood pressure and mortality - implications from a cohort of 361662 men. Lancet 1986;ii:933-6.

5 Lipid Research Clinics Program. The Lipid Research Clinics Program coronary primary prevention trial results. II nics Program coronary primary prevention trial results. II
- The relationship of reduction in incidence of coronary heart disease to cholesterol lowering. $\mathscr{\text { T }} A M A$ 1984; 251:365-74.

6 Frick MH, Eloo O, Haapa $\mathrm{K}$, et al. Helsinki heart study: primary prevention trial with gemfibrozil in middle aged men with dyslipidaemia. $N$ Engl 7 Med 1987;317:123745.

7 National Heart Lung and Blood Institute and National Institute of Health Office of Medical Applications of Research. Consensus conference on lowering blood cholesterol to prevent heart disease. $\mathcal{F} A M A$ 1985;253:2080-6.

8 Muldoon MF, Manuck SB, Matthews KA. Lowering cholesterol concentration and mortality: a quantitative review of primary prevention trials. BMF 1990;301:309-13.

9 Rose G, Shipley $M$. Effect of coronary risk reduction on the pattern of mortality. Lancet 1990;i:275-7. trol group in those with an initial value $\geqslant 6.5 \mathrm{mmol} / 1$ was less than anticipated in the 
10 Ravnskov U. Cholesterol lowering trials in coronary heart disease: frequency of citation and outcome. $B M F 1992$; 305:15-19.

11 Shepherd J, Betteridge DJ, Durrington P, et al. Strategies for reducing coronary heart disease and desirable limits for blood lipid concentrations: guidelines of the British Hyperlipidaemia Association. BMF 1987;295:1245-6.

12 Smith GD, Pekkanen J. Should there be a moratorium on the use of cholesterol lowering drugs. BMY 1992; $304: 431-4$

13 Oliver MF. Might treatment of hypercholesterolaemia in-

14 Ramsay LE, Yeo WW, Jackson PR. Dietary reduction of serum cholesterol concentration - time to think again BMF 1991;303:953-7.

15 Leeder S, Gliksman M. Prospects for preventing coronary heart disease - population based approaches (editorial) $B M \mathcal{A}$ 1990;301:1004-5.

16 King's Fund Forum. Blood cholesterol measurement in the prevention of coronary heart disease, a consensus statement. London: King's Fund, 1989. King's Fund consensus conference.

17 Standing Medical Advisory Committee. Blood cholesterol testing: report to the Secretary of State for Health. London: testing: report to the Secretary

18 Australasian Epidemiological Association policy statement on cholesterol testing. F Public Health Med 1992;14:344 5.

19 Robertson I, Phillips A, Mant D, et al. Motivational effect of cholesterol measurement in general practice health checks. Br f Gen Pract 1992;42:469-72.

20 Van Beurden E, James R, Dunn T, Tyler C. Risk assessment and dietary counselling for cholesterol reduction. Health Education Research 1990;5:445-50.

21 Kinlay S, Heller RF. Effectiveness and hazards of case finding for a high cholesterol concentration. $B M \mathcal{F}$ 1990;300:1545-7.

22 Natelson BH, Tapp WN, Munsif A, Burns W. Fluctuating serum cholesterol: implications for coronary prevention. Lancet 1989;ii:404-5.

23 Armitage P, Berry G. Statistical methods in medical research. Oxford: Blackwell, 1987:181-2.

24 Kottke TE, Gatewood LC, Park H-A. Using serum cholesterol to identify high risk and stimulate behaviour change: terol to identify high risk and stimulate
will it work? Ann Med 1989;21:181-7.

25 Turpeinen O, Karvonen MJ, Pekkarinen M, Miettinen M, Elosuo R, Paavilainen E. Dietary prevention of coronary heart disease: the Finnish mental health study. Int $\mathcal{F}$ Epidemiol 1979;8:99-118.

26 Neil HAW, Mant D, Jones L, Morgan B, Mann JI. Lipid screening: is it enough to measure total cholesterol concentration. $B M F$ 1990;301:584-7.

27 Gordon DJ, Trost DC, Hyde J, et al. Seasonal cholesterol cycles: the Lipid Research Clinics coronary primary prevention trial placebo group. Circulation 1987;76:1224-31.

28 Gordon T, Kannel WB, Castelli WP, Dawber TR. Lipoproteins, cardiovascular disease, and death. The Framingham study. Arch Intern Med 1981;141:1123-31.

29 Pocock SJ, Shaper AG, Phillips AN. Concentrations of high density lipoprotein cholesterol, triglycerides, and high density lipoprotein cholesterol, triglycerides, and 1989;298:998-1002.

30 Hjermann I, Enger SC, Helgeland A, Holme I, Leren P, Trygg $\mathrm{K}$. The effect of dietary changes on high density lipoprotein cholesterol: the Oslo study. $A m$ f $\mathrm{Med}$ 1979;66:105-9.

31 Van Beurden E, James R, Tyler C, Henrikson D. Cholesterol reduction is sustainable: 12 month follow-up of a cholesterol campaign in rural Australia. Health Education fournal 1990;49:181-4. 